\title{
Bentuk arsitektur sebagai media komunikasi ritual pengobatan suku Akit di pulau Rupat
}

\author{
Gun Faisal ${ }^{1}$ dan Genny Gustina Sari ${ }^{2}$ \\ ${ }^{1,2}$ Universitas Riau, Pekanbaru, Indonesia
}

\begin{abstract}
ABSTRAK
Salah satu bentuk aktivitas komunikasi terjadi pada ritual Bedekeh yang dilakukan oleh Suku Akit di Pulau Rupat. Ritual Bedekeh merupakan sebuah ritual pengobatan dimana seorang Bomo (dukun) menjadi perantara antara si sakit dengan arwah nenek moyang yang dipercayai mampu menyembuhkan penyakit. Dalam ritual Bedekeh terdapat aktivitas komunikasi ritual yang sarat dengan makna dan simbol khususnya dari segi bangunan arsitektur serta peralatan yang digunakan Bomo dalam ritual ini. Penelitian ini dilakukan untuk mengkaji bagaimana bentuk arsitektur berfungsi sebagai media pengobatan masyarakat suku Akit. Kajian ini membahas bentuk tidak hanya sebagai bagian dari arsitektur tetapi juga bagian dari ritual dan kebudayaan. Metode penelitian kualitatif dengan pendekatan etnografi digunakan dalam penelitian ini. Penelitian dimulai dengan mengkaji bentuk arsitektur vernakular dan ritual Bedekeh sebagai background knowledge, dilanjutkan dengan mengumpulkan informasi mengenai tata cara dan ritual pengobatan tersebut. Selanjutnya melihat elemen-elemen arsitektur yang terdapat dalam cara pengobatan beserta fungsi dan maknanya. Berdasarkan temuan lapangan, model Rumah Roh (Huma) dan Istana (Balai) digunakan sebagai media komunikasi antara Bomo (dukun) dengan para roh, jin, maupun hantu. Bentuk dari model Huma dan Balai tersebut tercipta dari wahyu atau bayangan, maupun mimpi Bomo sesuai dengan keinginan roh tersebut. Proses pembuatan Balai dilakukan oleh Bomo dan keluarganya, sedangkan model Huma dikerjakan oleh keluarga pasien dan tetangga pasien. Jika dilihat dari proses terciptanya bentuk dari Balai dan Rumah Roh tersebut, bentukan itu terlihat lazim seperti bentuk dari rumah suku Akit itu sendiri.
\end{abstract}

Kata-kata Kunci: Akit; Bedekeh; komunikasi ritual; model arsitektur; pengobatan

\section{Architectural form as ritual treatment communication media of Akit people in Rupat island}

\begin{abstract}
One form of communication activity occurs in the Bedekeh ritual carried out by the Akit tribe on Rupat Island. Bedekeh ritual is a medical ritual in which a Bomo (dukun) becomes an intermediary between the sick and ancestral spirits believed to be able to cure disease. In the Bedekeh ritual there are ritual communication activities that are full of meanings and symbols, especially in terms of the architectural building and equipment used by Bomo in this ritual. This research was conducted to study how the form of architecture serves as a medium for treatment of Akit society. This study discusses forms not only as part of the architecture but also part of the ritual and culture. Qualitative research method with ethnography approach used in this research. The study begins by examining the vernacular forms and Bedekeh ritual as background knowledge, followed by collecting information on the procedures and rituals of such treatment. Next look at the architectural elements contained in the way of treatment along with the function and its meaning. Based on field findings, the model of Spirit House (Huma) and Castle (Balai) is used as a medium of communication between Bomo (shaman) with the spirits, jinns, and ghost. The form of the Huma and Balai model are created by revelation or shadow, as well as Bomo's dream in accordance with the spirit's wishes. The process of making Balai is done by Bomo and his family, while the Huma is done by the patient's family and the patient's neighbors. When viewed from the process of creating the shape of the Castle and the Spirit House, the formation looks as common as the form of the house of the Akit tribe itself.
\end{abstract}

Keywords: Akit; Bedekeh; modelling architecture; ritual communication; shamanism

Korespondensi: Gun Faisal, S.T., M.Sc., Prodi Arsitektur Universitas Riau, Kampus Bina Widya, Jl. HR Subrantas KM 12.5, Simpang Baru, Pekanbaru, Riau, 28293.Email: gunfaisal@eng.unri.ac.id. 


\section{PENDAHULUAN}

Suku Akit merupakan komunitas adat yang terdapat di Provinsi Riau. Suku Akit juga disebut sebagai suku Laut karena sebagian besar aktivitas mereka berhubungan dengan laut. Selain menangkap ikan, mata pencaharian mereka adalah memanfaatkan kayu Bakau sebagai Kayu Arang. Kata Akit berasal dari kata rakit, suku Akit secara singkat dapat dikatakan suku rakit, orang rakit atau tukang rakit (Firzal, Rijal, \& Faisal, 2017). Selain itu, Osawa (2009) mengatakan nama "akit (rakit)" dikatakan berasal dari kebiasaan masa lalu mereka membangun rumah di atas rakit. Sedangkan WBC Wintgest dan E.M Unlenbech dalam encyclopaedic van Nederlansche Indie, berpendapat bahwa orang Akit termasuk keturunan bangsa Negritisch (Negrito) hal ini terlihat dari perawakan mereka yang bertubuh besar kekar dan berambut keriting (Limbeng, 2011).

Salah satu wilayah yang dimukimi oleh suku Akit dan masih eksis hingga saat ini adalah Pulau Rupat, Provinsi Riau. Suku Akit sampai saat ini masih mempertahankan berbagai bentuk kebudayaannya, seperti sistem kepercayaan, kesenian, ritual dan upacara-upacara adat. Salah satu ritual yang masih dipertahankan yaitu Bedekeh. Bedekeh, Bedikie atau Berdeker merupakan salah satu ritual pengobatan suku Akit, Bedekeh ini merupakan pengobatan besar atau ritual pengobatan sakral (Suroyo, Wirata, \& Kamaruddin, 2017). Dalam proses Bedekeh ini digunakan "Balai" dan "Huma" sebagai salah satu syarat ritual tersebut. Balai dan Huma

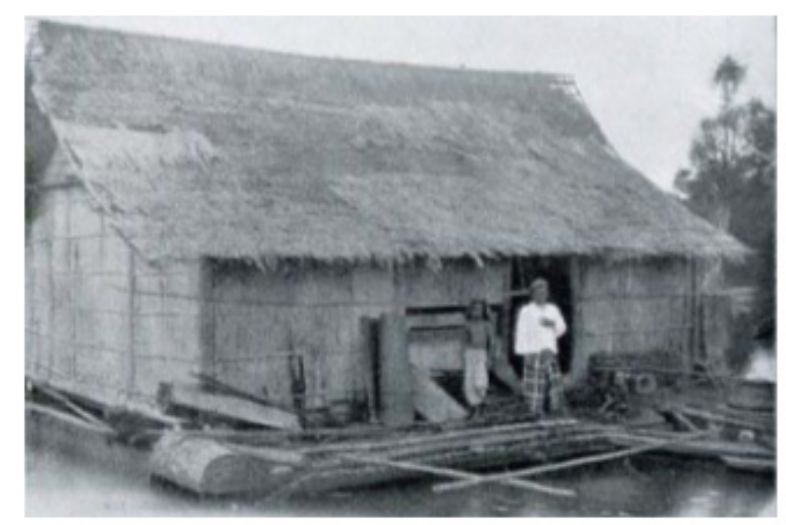

Sumber: Moszkowski (dalam Osawa, 2009)

Gambar 1 Rumah diatas Rakit (Huma Akit) di Sungai Siak awal Abad 20 dapat dikategorikan sebagai bentuk arsitektur yang menyerupai bangunan yang digunakan dalam ritual ini.

Berbagai macam budaya percaya bahwa penyakit dan kesehatan diperoleh dari cara pandang kelompok masyarakat yang disampaikan dari generasi ke generasi. Kepercayaan ini bervariasi dari satu budaya ke budaya lain dan merujuk pada konsep tentang penyakit yang berbeda. Menurut Andrews (Samovar, Porter, \& McDaniel, 2010) umumnya, teori mengenai kesehatan dan penyebab penyakit didasarkan pada pandangan yang dimiliki oleh suatu kelompok. Pandangan ini meliputi sikap, kepercayaan dan praktikpraktik suatu kelompok terhadap kesehatan, dan biasanya disebut dengan sistem kepercayaan kesehatan.

Tradisi pelayanan kesehatan yang berdasarkan kekuatan supernatural atau magis maupun religious datang dari sistem kepercayaan dimana dunia dianggap sebagai arena kekuatan supernatural yang mendominasi. Pengikut tradisi ini memegang kepercayaan yang kuat mengenai keberadaan ilmu sihir, kekuatan magis dan roh jahat. Dalam sistem ini, penyakit berhubungan dengan kekuatan spiritual seperti ilmu sihir, melanggar hal-hal yang dianggap tabu oleh masyarakat, menganggu objek yang sakit, menganggu roh atau bermain-main dengan dunia spiritual hingga menyebabkan orang sakit bahkan meninggal merupakan sebagian dari begitu banyak alasan penyakit yang ditimbulkan akibat kemarahan semesta dan penguasa alam (Samovar, Porter, \& McDaniel, 2010).

Dalam tradisi suku Akit, dukun atau yang mereka sebut sebagai Bomo berperan sangat penting dalam proses pengobatan khususnya penyakit-penyakit yang mereka yakini disebabkan oleh gangguan makhluk halus (jin) atau penyakit yang disebabkan oleh Bedekeh atau Bedeker. Sebagai penganut kepercayaan animisme, masyarakat suku Akit masih menganggap bahwa Bomo (dukun) adalah orang pintar yang mampu mengobati penyakit yang mereka anggap tidak wajar atau tidak mungkin bisa ditangani oleh medis (Limbeng, 2011).

Menurut Foster dan Anderson penyakit merupakan salah satu gangguan yang sangat besar, penyakit dari roh-roh yang ada disekitar sebagai bentuk peringatan kepada masyarakat. Dalam suatu sistem personalistik, suatu sistem di mana penyakit (illness) disebabkan oleh 
intervensi dari mahluk supranatural (mahluk gaib atau dewa), mahluk yang bukan manusia (seperti hantu, roh leluhur dan roh jahat), maupun mahluk manusia (tukang sihir atau tukang tenung) (Harsono \& Jonyanis, 2014).

Dalam tradisi supranatural, pengobatan melibatkan hubungan postif dengan rohroh, dewa-dewa dan sebagainya. Pengobatan dilaksanakan oleh seorang penyembuh atau yang biasa disebut sebagai dukun. Kepercayaan terhadap dukun ditemukan dibeberapa budaya bagian dunia, dimana mereka meyakini hidup melalui bantuan mistis atau hubungan spiritual dengan apa yang mereka yakini. Umumnya, dukun kelihatan akan memohon kekuatan yang lebih besar daripada kekuatan fisik yang dimikinya pada penguasa alam. Kekuatan tersebut bisa melalui tumpang tangan untuk menyembuhkan penyakit dengan menghilangkan roh-roh yang berbahaya dan mengembalikan energi tubuh. Kemampuan ini juga diperkuat dengan kemampuan berhubungan dengan roh nenek moyang yang berpengaruh atau berkuasa yang bisa memberikan informasi atau bantuan demi kesembuhan pasien.

Suku Akit dalam mengobati penyakit khususnya penyakit yang diyakini masyarakat sebagai teguran dari penguasa alam atau gangguan jin dan makhluk halus juga menggunakan serangkaian ritual keagamaan. Perangkat pengobatan disiapkan oleh Bomo sebagai kepala ritual, dan asistennya disebut Bebayu, serta seorang pemain musik atau penabuh gendang yang disebut Bidung. Proses pengobatan biasanya dilakukan pada malam hari dan terdiri dari beberapa rangkaian kegiatan. Salah satu rangkaian kegiatan adalah adanya syarat Bedekeh yaitu Balai (istana) dan Huma (rumah).

Balai dan Huma merupakan bagian dari bentuk arsitektur. Malangyudo \& Subroto (2013) mengatakan prinsip arsitektur secara substansial akan selalu berorientasi dan tersusun dari tiga aspek utama yaitu: bentuk (form), ruang (space) dan susunan (order).

Secara harfiah ilmu tentang bentuk disebut Morfologi. Morfologi berasal dari kata morphology (Inggris) yang berarti ilmu bentuk (morphos). Morfologi merupakan ilmu yang mempelajari bentuk dan susunannya serta perubahannya. Zwicky mengemukakan bahwa morfologi berhubungan dengan studi tentang bentuk secara geometrik dan struktur material secara umum, sekaligus berhubungan dengan hal yang lebih abstrak seperti hubungan struktural diantara fenomena, kegiatan, konsep, dan ide. Morfologi lebih menekankan pada "bagaimana" bentuk bangunan itu, dan dalam satu karya arsitektur dinyatakan sebagai "artikulasi formal", dimana karakter dari bentuk ditentukan oleh batas-batasnya (Faisal \& Wihardiyanto, 2016). Morfologi menurut Schulz menyangkut kualitas figural dalam konteks wujud pembentuk ruang yang dapat dibaca melalui pola, hirarki dan hubunganhubungan ruang satu dengan lainnya (Syahrozi, 2013).

Dalam proses terciptanya bentuk, Wardani (2010) menyatakan ruang terdiri atas titik (tempat beberapa bidang bertemu), garis (tempat dua bidang berpotongan) dan bidang (sebagai batas-batas ruang), sehingga terciptalah bentuk. Kembali Wardani (2010) menyatakan seni bangunan akan terus berkembang karena berfungsi untuk memuaskan (1) kebutuhan individu tentang ekspresi pribadi yang mengkomunikasikan perasaan dan ideide personal, (2) kebutuhan sosial untuk berkomunikasi dan mengekspresikan atau menjelaskan aspek-aspek tentang eksistensi sosial atau kolektif, dan (3) kebutuhan fisik mengenai bangunan-bangunan yang bermanfaat. Arsitektur sebagai artefak adalah fenomena sensoris yang mengandung makna implisit, yakni makna konseptual, makna fisik yang terkait dengan fungsi sosial, dan makna bendawi/artefak. Mangunwijaya (Marlinda, Barliana, \& Krisnanto, 2013) mengatakan bahwa berarsitektur artinya berbahasa dengan ruang dan gatra, dengan garis dan bidang, dengan bahan material dan suasana tempat.

Penelitian ini dilakukan agar dapat mengkaji bagaimana bentuk arsitektur berfungsi sebagai media pengobatan masyarakat suku Akit. Kajian ini membahas bentuk tidak hanya sebagai bagian dari arsitektur tetapi juga bagian dari ritual dan kebudayaan masyarakat suku Akit. Selain itu penelitian ini mencoba melihat makna dan bentuk arsitektur dari sudut pandang masyarakat suku Akit serta bagaimana bentuk tersebut tercipta berdasarkan lokalitas dan interpretasi vernakular masyarakat. Bentuk arsitektur tersebut masih dipercayai sebagai sesuatu yang memiliki nilai mistis dan historis yang harus dilestarikan.

Dalam rangka untuk menggambarkan dan 
menganalisis komunikasi Hymes membagi ke dalam tiga unit analisis, meliputi situasi (situation), peristiwa (event), dan tindak (act). Situasi komunikatif (communicative situation) merupakan konteks di mana komunikasi terjadi seperti upacara, perkelahian, perburuan, pembelajaran di dalam ruang kelas, konferensi, pesta dan lain sebagainya. Peristiwa komunikatif (communicative event) merupakan unit dasar untuk sebuah tujuan deskriptif komunikasi yang sama meliputi: topik yang sama, peserta yang sama, ragam bahasa yang sama. Tindak komunikatif (communicative act) umumnya berbatasan dengan fungsi tunggal interaksional, seperti pernyataan referensial, permintaan, atau perintah, yang mungkin berupa tindak verbal atau tindak nonverbal (Anshori, 2017).

\section{METODE PENELITIAN}

Metode penelitian kualitatif
pendekatan engan
penelitian ini. Maleong (Fadhilah \& Dewi,
2017) menyatakan istilah etnografi berasal dari ethno (bangsa) dan graphy (menguraikan), jadi etnografi yang dimaksud adalah usaha untuk menguraikan kebudayaan atau aspek-aspek kebudayaan. Dimana dalam penelitian ini yang dipelajari adalah kebudayaan masyarakat suku Akit, dengan tujuan untuk mengetahui bentuk arsitektur dalam budaya pengobatan suku Akit. Sedangkan Tandyonomanu \& Bahfiarti (2013) berpendapat Etnografi adalah penelitian untuk mendeskripsikan kebudayaan sebagaimana adanya.

Penelitian dimulai dengan mengkaji bentuk arsitektur vernakular dan mengkaji kebudayan Bedekeh masyarakat suku Akit sebagai background knowledge, dilanjutkan dengan mengumpulkan informasi mengenai tata cara dan media pengobatan tersebut. Selain itu melihat elemen-elemen arsitektur yang terdapat dalam cara pengobatan beserta fungsi dan makna yang ada di dalamnya. Informasi yang telah dikumpulkan selanjutnya dianalisa dari berbagai sudut. Selanjutnya analisa tersebut disusun berdasarkan urutan tertentu guna melihat serta merumuskan secara tertulis sehingga dapat melihat fungsi dan makna dari bentuk arsitektur dalam ritual tersebut.

Data diperoleh dengan cara story-telling, dokumentasi dan observasi lapangan serta semistruktur wawancara. Key-informan yang dipilih dilakukan secara purposive yaitu pengambilan data dengan cara memilih orang-orang tertentu berdasarkan pada kelompok, wilayah, atau sekelompok individu melalui pertimbangan tertentu yang diyakini mewakili semua unit analisis yang ada (Hamidi dalam Khomsa \& Nurjanah, 2015). Informan terdiri dari 5 orang: Pemuka adat Suku Akit sebanyak 1 orang, yaitu Pak Bukyan (Batin Suku Akit), 2 orang dukun (Bomo) dan seorang pembantu dukun, serta 2 orang warga yang pada saat penelitian menjadi pasien Bomo. Informan tersebut dapat menunjukan dan mempraktekkan langsung ritual bedekeh sebagai cara pengobatan masyarakat suku Akit.

Observasi dilakukan dengan melihat secara langsung proses Bedekeh tersebut. Peneliti juga melakukan dokumentasi (video) cara Bedekeh suku Akit untuk menunjang proses penelitian. Setelah observasi dilakukan, peneliti selanjutnya melakukan wawancara semiterstruktur sesuai dengan tujuan penelitian. Dalam proses penelitian dilakukan eksplorasi cara dengan melihat keadaan dilapangan.

Metode analisis data yang digunakan adalah analisis iterasi induktif dengan titik tolak dari data-data yang dikumpulkan di lapangan. Data yang telah dikumpulkan kemudian diproses dan diverivikasi dari berbagai sumber dan sudut pandang. Berdasarkan hasil survey, hasil observasi, dan hasil wawancara serta cerita dari narasumber di lapangan, akan disusun berdasarkan tata cara pengobatan Bedekeh serta melihat makna dan kegiatan yang ada di dalam kegiatan tersebut. Sedangkan validasi data akan dilakukan melalui metode triangulasi data. Trianggulasi data yaitu melihat similaritas berbagai data yang diperoleh dari metode pengumpulan data yang berbeda (Leuape \& Dida, 2017).

\section{HASIL DAN PEMBAHASAN}

Ritual pengobatan bagi suku Akit disebut Bedekeh. Bedekeh merupakan ritual khusus untuk mengusir roh jahat yang menganggu masyarakat. Masyarakat suku Akit meyakini bahwa segala penyakit bersumber dari roh jahat baik itu penyakit ringan maupun penyakit berat yang dapat berujung pada kematian. Ritual bedekeh dipimpin oleh seorang dukun yang disebut sebagai Bomo.

Bomo adalah orang pintar yang memiliki 
kemampuan untuk menjalin komunikasi dengan arwah-arwah leluhur dan makhluk gaib. Bomo bertugas menjadi media yang menyampaikan pesan dari makhluk gaib kepada si sakit (pasien) tentang informasi penyakit yang dideritanya. Bomo ditunjuk oleh arwah leluhur yang diturunkan secara garis kekeluargaan. Oleh karena itu Bomo dianggap sebagai satusatunya solusi bagi penyakit yang tidak bisa disembuhkan melalui pengobatan medis pada umumnya. Biasanya yang menjadi Bomo adalah anak pertama atau anak terakhir sesuai dengan pilihan arwah leluhur mereka yang juga menjadi Bomo dulunya.

roh moyang mengajarkan kami lewat mimpi dan dipilih sesuai maunya roh moyang $t u$, biasanya kalau ndak anak pertama ya anak bungsu (Wawancara dengan Bomo Bandawan).

Setiap Bomo memiliki pegangannya masing-masing, ada yang mengaku berpegang pada roh Anak Mamang Raja Dilaut, ada yang mengaku berpegang pada Raja Darat dan orang-orang kuat pada zaman dulu yang diyakini oleh para Bomo memberikan kekuatan kepada mereka melalui mimpi. Setiap Bomo akan ditunjuk oleh roh moyang diajari dan diberi kemampuan melalui media mimpi.

Ritual bedekeh sendiri dimulai dari pengaduan masyarakat yang sakit kepada Bomo. Bomo kemudian meminta beberapa alat dari diri si sakit untuk menjadi media penghubung arwah kepada si sakit untuk membantu melihat roh jahat mana yang menganggu si sakit. Beberapa benda yang diminta oleh Bomo biasanya baju yang dipakai dan belum dicuci oleh si sakit, tikar atau alas tidur (masyarakat suku Akit jarang tidur di kasur, mereka lebih senang tidur diatas tikar pandan) atau lainnya. Beberapa alat atau perkakas si sakit ini bermakna diri yang menjadi kekhasan si sakit. Adapun pemilihan benda-benda didasarkan pada benda-benda yang sering dan selalu digunakan seperti tikar atau alas tidur. Bagi Bomo alat tersebut akan menjadi pengganti diri si sakit saat nanti berkomunikasi dengan roh leluhurnya.

Dalam konsep etnografi komunikasi dimana terdiri dari tiga unit analisis yakni situasi, peristiwa dan tindak komunikatif. Dalam ritual bedekeh kita melihat situasi sebagai dimana lokasi ritual ini dilaksanakan, dalam hal ini dilaksanakan di rumah Bomo.
Sementara dari sisi peristiwa komunikatif merupakan bagian dari situasi yang terjadi. Dalam ritual bedekeh, peristiwa komunikatif dimulai sejak si sakit mendatangi Bomo hingga proses penyembuhan dinyatakan selesai dan si sakit membayar persembahan untuk wahyu yang menyembuhkannya. Unit analisis terakhir yakni tindak komunikatif didasari pada tindak verbal dan no verbal yang sifatnya sakral hal ini terdiri dari ucapan Bomo hingga tindakan nonverbalnya pada saat proses bedekeh.

Para Bomo menyatakan bahwa alam gaib dikuasai oleh dua jenis makhluk (jin). Jin jahat yaitu jin yang menganggu manusia dan biasanya menjadi penyebab datangnya penyakit dan jin baik atau yang biasa mereka sebut sebagai wahyu yang nantinya akan membantu mereka para Bomo untuk mengusir jin jahat dari dalam tubuh si sakit. Para Bomo mengakui, bahwa wahyu adalah roh moyang mereka yang bukan hanya menjadi perantara atau membantu mereka dalam mengobati orang sakit namun juga sebagai penjaga dan pelindung para Bomo dan keluarganya.

Secara umum, Osawa (2009) mengatakan proses Bedekeh terdiri dari 6 proses, prosedur utama masing-masing dibagi menjadi beberapa tahap, yaitu; (1) Membuat obat; (2) Memberikan tiupan magis dan mantra; (3) Diagnosis; (4) Persembahan; (5) Menunjukan jalan arwah; dan (6) Memanggil kembali jiwa pasien. Ritual bedekeh biasanya dilakukan pada malam hari. Setelah Bomo meminta barang si sakit, pada malam harinya si sakit akan datang kembali kerumah Bomo membawa alat yang diminta kemudian ritual Bedekeh pun dimulai. Bomo akan memanggil roh moyang untuk datang dan masuk ketubuhnya, nantinya akan ada pembantu Bomo (Bebayu) yang biasanya dari keluarga atau kerabat Bomo membantu Bomo berinteraksi dengan roh moyang atau wahyu tersebut.

Berdasarkan hasil diagnosa pada malam pertama, kemudian dipilihlah sesaji yang tepat untuk bedekeh malam berikutnya. Osawa (2009) dalam penelitianya mengatakan persembahan utama bagi roh yang dipanggil adalah beberapa model rumah atau perahu dan berbagai jenis makanan seperti kembang gula, pisang, tembakau, nasi kering, nasi kuning, telur, kacang, pinang, dan sebagainya. Makanan ini diletakkan di atas beberapa nampan, dan selama proses bedekeh miniature model rumah 
dan perahu di goyang-goyangkan di sekitar pasien. Kemudian pada akhirnya pemuda desa membawa keluar model rumah tersebut, dan ditinggalkan di hutan atau dihanyutkan di atas laut maupun di atas sungai.

Setelah mengetahui penyebab sakitnya, wahyu yang mendiami tubuh Bomo akan meminta sesajian kepada si sakit jika penyakitnya disembuhkan. Masyarakat suku Akit menganggap ini sebagai hutang yang harus dibayar secepatnya. Biasanya akan diadakan acara besar dalam rangka memperingati hari ulang tahun wahyu yang membantu Bomo dan tahun baru atau yang mereka sebut sebagai acara "Bedak Tahunan". Pada saat acara besar tersebut para pasien yang sudah sembuh akan membayar hutang atau sekedar mengucap terimakasih atas kesembuhan yang mereka dapat dari wahyu.

wahyu tu lah yang bantu kami sembuhkan si sakit kan.. nantik orang yang sakit tu bayar utang besok malamnya sesuai mintak wahyu atau kalau ndak mampu pas acara besar bulan 1 dan bulan 7 tu lah bayar hutang, tak payah besar-besar... garam dan gula sikit aja dah boleh... (wawancara dengan Bomo Bandawan)

Bedekeh merupakan ritual pengobatan masyarakat suku Akit yang dipraktekkan secara turun temurun. Meskipun sistem pengobatan modern telah menyentuh mereka, namun sebagian besar masyarakat Akit tetap percaya pada kekuatan Bomo untuk menyembuhkan penyakit-penyakit mereka mulai dari penyakit ringan hingga penyakit berat.

Dalam proses Bedekeh suku Akit, kita akan menemui sebuah Balai (model istana) yang ditempatkan di dalam rumah Bomo. Masingmasing Bomo di suku Akit memilih Balai mereka sendiri, dengan berbagai bentuk dan ukuran. Semua ketentuan Balai dikembalikan pada wahyu yang menjadi "pegangan" para Bomo. Dua orang informan dalam penelitian ini, yaitu Bomo Baut dan Bomo Bandawan memiliki jenis Balai yang berbeda.

Bomo Baut menyebut Balai adat yang dimilikinya sebagai Balai Adat Bohohok sedangkan Bomo Bandawan memiliki Balai yang diberi nama Balai Anak Mamang Raja Dilaut. Hal yang menarik dalam proses pembuatan Balai adalah bahwa masing-masing Bomo tidak membuat Balai sesuai keinginan

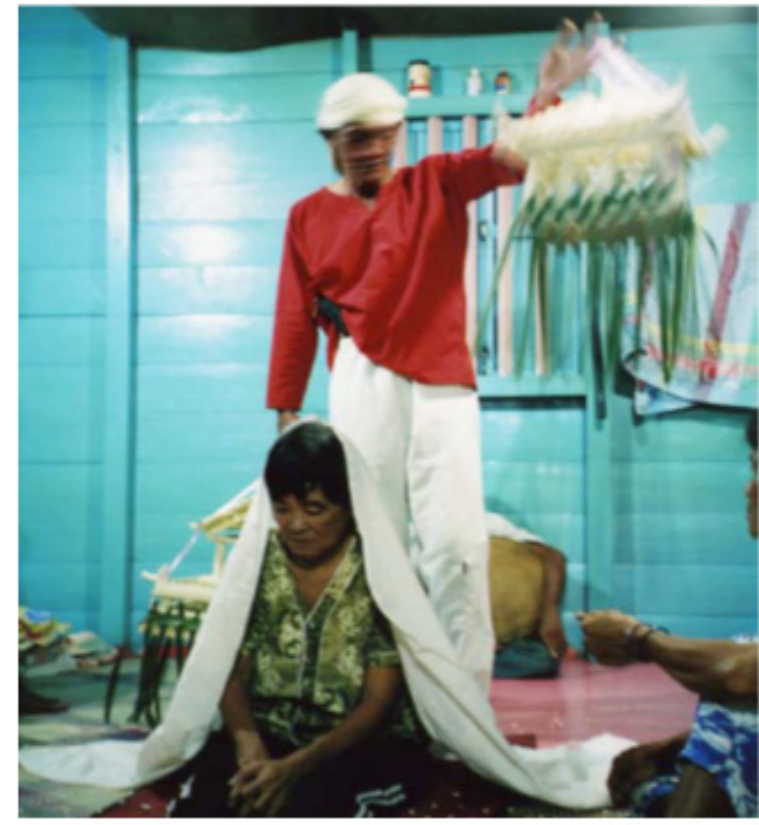

Sumber: Osawa, 2009

Gambar 2 Bomo Menggoyang - goyangkan Model Rumah dalam Ritual Bedekeh

mereka melainkan sesuai keinginan wahyu "pegangan" mereka seperti yang diungkapkan oleh Bomo Bandawan berikut ini:

balai tu dibuat pakai kayu gaharu... modelnya kami dapat dari wahyu, wahyu $t u$ kasih penglihatan yang tebayang-bayang aja di mata kami menjelang jadi balai tu jadi macam $t u$ kehendak wahyu, macam $t u$ kami buat.

Biasanya Balai terdiri dari 4 tiang utama untuk menaungi atap yang terbuat dari kayu pohon gaharu, sebagai pengikat mereka menggunakan akar kayu lahak hal ini disebabkan masyarakat Suku Akit dalam mendirikan bangunan baik itu rumah atau tempat ibadah tidak menggunakan paku melainkan pasak yang juga terbuat dari kayu gaharu dan pengikat dari akar kayu lahak.

Dalam pembuatan balai adat pengobatannya, Bomo biasanya dibantu oleh keluarganya saja, hal ini dikarenakan hanya Bomo saja yang mengetahui bagaimana sebenarnya bentuk Balai adat yang diinginkan oleh wahyu pegangannya tersebut. Lama proses pembuatan Balai biasanya memakan waktu selama 1-2 bulan. Selama proses pembuatan, Bomo mengakui bahwa wahyu dapat kapan saja merubah bentuk yang diinginkannya sehingga memakan waktu yang cukup lama. Beberapa 


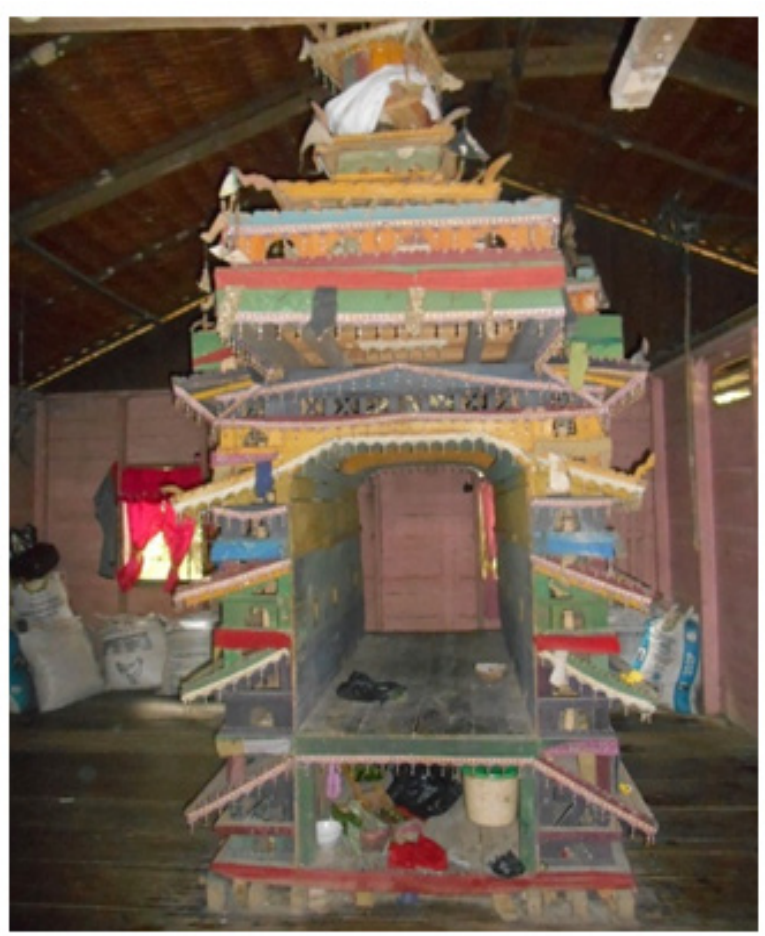

Sumber: Dokumentasi, 2017

\section{Gambar 3 Balai Adat Bohohok}

hiasan pada Balai ditentukan juga oleh wahyu. Intinya Bomo hanya mengikuti kehendak wahyu saja.

Besarnya kepercayaan masyarakat suku Akit kepada kekuatan roh baik dan roh jahat masih mendominasi dalam kehidupan mereka. Bedekeh bukan menjadi alternative melainkan bentuk keyakinan mereka bahwa alam semesta ini dikuasai oleh roh dan gaib.

Setiap balai memiliki penanda, penanda disini maksudnya adalah alat untuk mengetahui kapan atau saat roh atau wahyu mendatangi tubuh Bomo. Pada Balai Adat Bohohok, Bomo Baut menggunakan rumbai renda yang diberi mainan seperti kerincing diujung renda berbentuk segitiga. Jika wahyu mendatangi tubuhnya, maka renda akan bergerak tertiup angina dan kerincing berbunyi nyaring.

Sedangkan pada Balai Adat Anak Mamang Raja Dilaut, Bomo Bandawan meletakkan kincir berbentuk bulat yang jika wahyu mendatangi tubuhnya maka kincir akan berputar dan wahyu melalui tubuh Bomo akan memainkan kincir tersebut. Masing-masing Bomo memiliki penanda tersendiri yang pada dasarnya berfungsi sebagai penyampai pesan bahwa wahyu telah datang.

Setelah Balai dibuat, Bomo akan mengisinya dengan sesajian yang beraneka

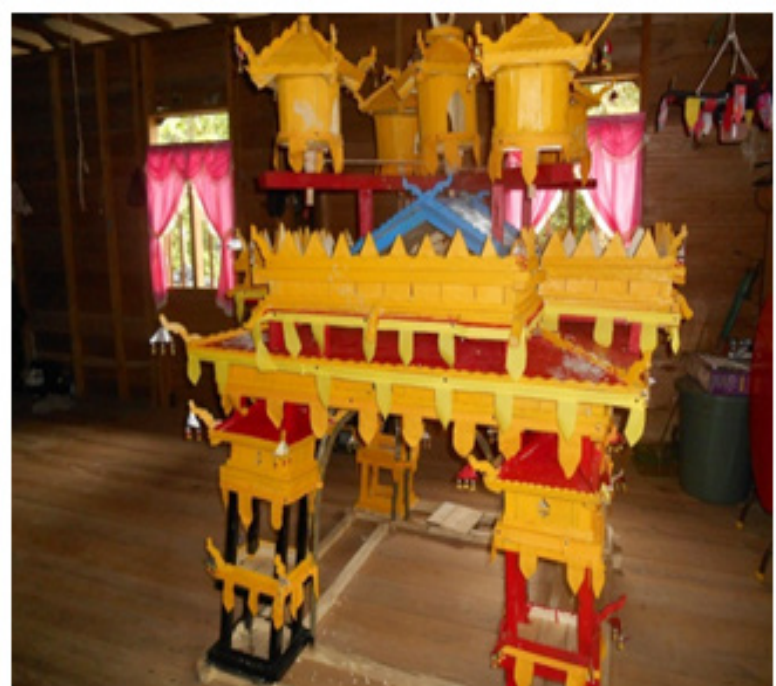

Sumber: Dokumentasi, 2017

\section{Gambar 4 Balai Adat Anak Mamang Raja Dilaut}

ragam, beberapa sesajian yang hampir umum dimiliki Bomo adalah Beretih, Buyung atau Pasu dan Bunga Taman. Beretih merupakan makanan bagi wahyu terbuat dari beras yang disangrai atau digoreng sehingga mengembang seperti kerupuk atau popcorn. Beretih akan diberikan oleh Bomo kepada wahyu, dalam prakteknya Bomo yang nantinya akan memakan Beretih saat wahyu merasukinya, masyarakat meyakini pada saat itu wahyu lah yang memakan Beretih bukan Bomo.

Buyung Pasu dan Bunga Taman adalah alat yang digunakan Bomo untuk dipercikkan ke pasien. Bedanya adalah Buyung atau Pasu berisi lilin yang dibuat dari sarang lebah sedangkan Bunga Taman berisi air. Buyung Pasu dan Bunga Taman dimaknai Bomo sebagai media atau alat yang disediakan oleh wahyu untuk menyembuhkan pasien. Lewat lilin atau air, telah terisi mantra penyembuh dari wahyu yang nantinya diyakini menjadi penyebab sembuhnya pasien.

Kembali Osawa (2009) mengatakan bahwa perbedaan perdukunan di Semenanjung Malaya dengan perdukunan di masyarakat Akit adalah penggunaan bentuk, dan simbolisme pada perlengkapan rumah roh (humah hantu), perahu roh (lancang), dan istana (balai). Dapat kita lihat bahwa bentuk arsitektur Rumah, Perahu dan Balai digunakan sebagai salah satu syarat proses pengobatan bedekeh tersebut.

Metode lain cara menghilangkan roh jahat atau penyakit adalah menarik keluar roh tersebut dari tubuh pasien. Bomo menangkap 
roh jahat dengan tangannya kemudian Bomo mengunci roh jahat ke dalam Huma dengan melakukan tarian. Bomo melemparkan dirinya ke Balai dan menangkap sesuatu. Objek yang ditemukan tersebut kemudian disegel kedalam Huma dengan hati-hati dengan kain dan dibuang jauh ke dalam laut. Teknik ini hanya digunakan bila roh-roh jahat dianggap sangat jahat.

Ritual penyembuhan biasanya diorganisir oleh satu Bomo, termasuk Bebayu, dan setidaknya satu Bidung. Pada ritual penyembuhan suku Akit, Model rumah, model kapal, dan model istana digunakan sebagai media penyembuhan tersebut. Model Rumah, Kapal dan Balai memiliki bentuk, struktur dan makna yang cukup canggih sekaligus memiliki tampilan yang menarik. Eliade, (2004) mengatakan kebiasaan ritual penggunaan perahu atau rumah bagi orang Indonesia dalam konteks perdukunan, sebagai; media untuk mengusir setan dan penyakit; dimana dukun Indonesia "berjalan melalui udara" untuk mencari jiwa pasien; "Perahu roh," yang membawa jiwa orang mati ke alam baka.

Model tersebut dibagi menjadi tiga kategori, yaitu Rumah Roh (Humah Hantu), Kapal Arwah (Lancang), dan Istana (Balai). Ketiga bentuk tersebut digunakan untuk penyembuhan ritual. Masyarakat Akit menyebut model tersebut sebagai "Barang sekali pakai (Bebuang). Rumah roh memiliki variasi bentuk dan ukuran. Ada yang berbentuk seperti Rumah Tradisional Melayu, Istana multi lantai, Masjid, Kapal, Rakit, dan lain sebagainya. Setiap rumah roh memiliki nama sesuai dengan desain atau maknanya.

Selama proses penyembuhan, dua sampai empat jenis model rumah dan kapal digunakan setiap pasien per malam. Sebelum proses pemanggilan roh, aneka sesajen disajikan di dalam rumah-rumah roh. Secara umum model rumah digunakan sebagai media memindahkan penyakit dari tubuh pasien ke alam bebas. Penyakit yang ada pada tubuh di pindahkan oleh Bomo, kemudian rumah tersebut dibawah ke hutan atau laut berdasarkan jenis roh atau penyakit yang diderita.

Berdasarkan apa yang dipaparkan oleh Rapoport bahwa rumah dibangun berdasarkan lingkungan fisik sangat mempengaruhi cara merekonstruksi dan mendekorasi rumah, namun desain rumah juga dipengaruhi oleh budaya tempat mereka membangunnya

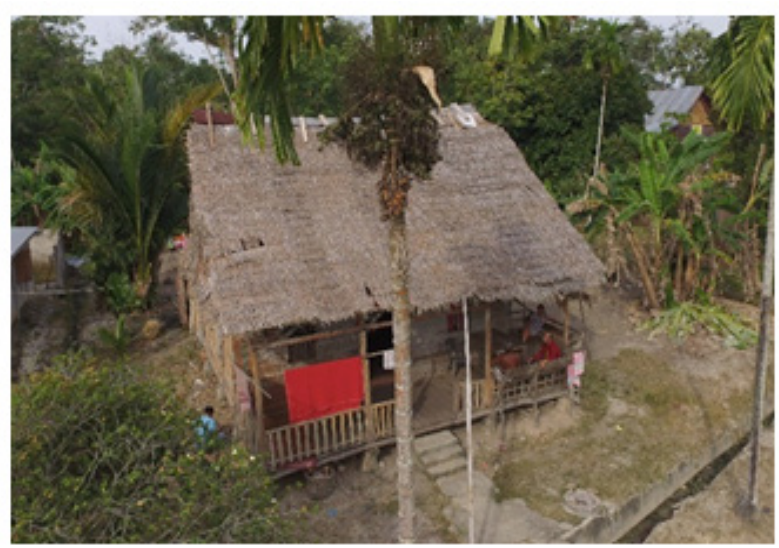

Sumber: Dokumentasi, 2016

\section{Gambar 5 Rumah Suku Akit Di Pulau Rupat}

(Tandyonomanu \& Bahfiarti, 2013). Pengunaan rumah (huma) dan istana (balai) sebagai media pengobatan suku Akit juga dipengaruhi dengan bagaimana Bomo mentransformasikan bentuk Huma dan Balai yang diinginkan oleh roh atau wahyu.

Kurniati (2015) mengatakan bahwa berkomunikasi (dalam arsitektur) berlangsung antara arsitek atau perancang (sebagai pembentuk sandi) dan pengguna atau masyarakat sebagai pembuka atau penerima sandi. Model Rumah dan Balai tersebut didapat oleh Bomo dalam bayangan mimpi dan wahyu yang dia terima. Jika dilihat secara kasat mata, bentuk rumah sebagai media komunikasi pengobatan tersebut di pengaruhi dengan bentuk rumah masyarakat suku akit itu sendiri (Gambar 1 dan Gambar 5).

Rumah dalam hal ini berarti ruangan tempat tinggal, bukan hanya sekedar fakta fisik saja. Rumah juga bisa memiliki arti simbolik tertentu ketika ruangan rumah tersebut diinteraksikan dengan pelaku-pelaku yang berada di dalamnya (Octavianti, 2016). Rumah roh disiapkan dimulai pada malam kedua proses Bedekeh. Bomo memutuskan jenis rumah roh dan juga sesaji yang sesuai untuk pemanggilan arwah berikutnya. Bomo memberitahu anggota keluarga pasien, nama rumah tersebut. Bomo mengatakan bahwa rumah roh tersebut digunakan untuk mengusir roh-roh jahat. Kemudian rumah roh juga digunakan sebagai persembahan untuk roh penjaga.

Dapat dilihat bahwa fungsi rumah roh sebagai media pengobatan berfungsi sebagai bagian dari komunikasi. Rumah roh berfungsi 
sebagai tempat penahanan roh yang dipindahkan dari tubuh sebelum dibawa ke laut atau hutan. Rumah roh juga sebagai sajian bagi roh-roh baik yang menjaga atau yang mengobati. Selain model rumah (rumah roh), model istana (balai) yang lebih besar juga digunakan sebagai media tempat pemanggilan arwah, atau roh-roh yang bekerja bersama Bomo, tempat singgah arwah ketika dipanggil Bomo, maupun sebagai tempat dimana Bomo dan roh-roh tersebut berdialog.

Dalam proses pengobatan ini, beberapa komponen penting yang tidak bisa dilewatkan atau digantikan karena memiliki peranan sentral adalah Bomo, peralatan si sakit dan wahyu. Komunikasi yang terjalin antara Bomo dan wahyu bukan tanpa sebab, melainkan dipersiapkan dan diupayakan untuk menolong si sakit.

Bomo dalam hal ini sebagai saluran komunikasi sekaligus tempat atau media yang memungkinkan komunikasi tersebut berlangsung. Bomo adalah lambang dari proses penyembuhan ini. Tokoh utama yang memegang peranan penting, maka Bomo di mata masyarakat seperti orang penting yang sangat diagungkan karena hanya Bomo saja yang mampu dan bisa menghubungkan si sakit dengan wahyu dan hanya Bomo yang menjadi perpanjangan tangan antara dunia nyata dengan alam gaib.

Komponen selanjutnya adalah peralatan si sakit. Peralatan si sakit yang dipilih memiliki makna sebagai represntasi diri si sakit yang akan dibawa oleh Bomo saat berkomunikasi dengan wahyu. Oleh karena itu, pemilihan peralatan tersebut didasari dari intensitas penggunaan barang tersebut dengan si sakit. Semakin sering barang tersebut digunakan, maka semakin kental dan kuat barang tersebut merepresentasikan diri si sakit dan semakin memudahkan wahyu untuk menerawang si sakit.

Komponen terakhir adalah wahyu atau roh baik. Masyarakat dan bomo menganggap wahyu adalah roh baik yang bertugas menjaga, melindungi, menyembuhkan si sakit. Wahyu adalah penolong, bukan tuhan namun sosok yang memudahkan mereka memaknai ketentuan tuhannya. Untuk beberapa kondisi, wahyu juga dianggap sebagai problem solving untuk permasalahan rumit seperti saat-saat harus membuat keputusan yang berat atau penentu pilihan yang harus diambil dari beberapa keputusan.

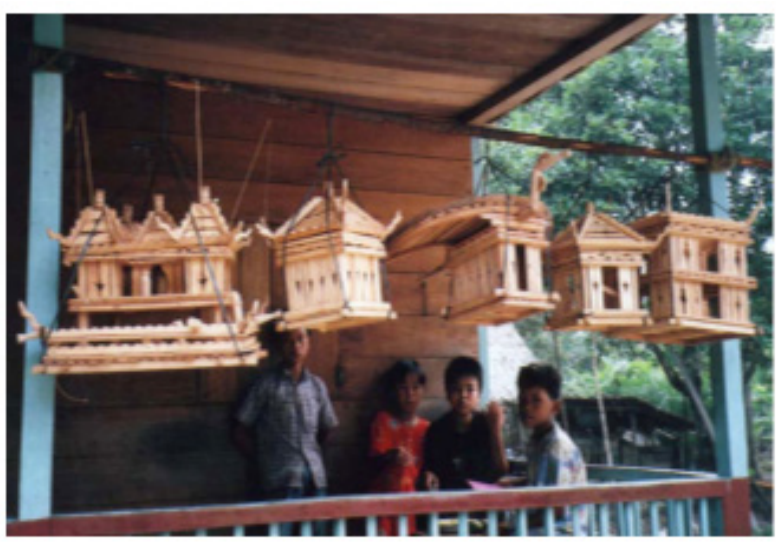

Sumber: Osawa, 2009

Gambar 6 Bermacam-macam Bentuk Model Rumah Untuk Ritual Bedekeh

\section{SIMPULAN}

Berdasarkan temuan lapangan, model Rumah dan Balai digunakan sebagai media komunikasi antara Bomo (dukun) dengan para roh, jin atau arwah dalam ritual pengobatan (Bedekeh) suku Akit di Pulau Rupat. Model Balai (istana) merupakan tempat Bomo berdialog ketika memanggil roh tersebut. Sedangkan model rumah roh (huma atau huma hantu) merupakan media tempat mengurung roh jahat yang dipindahkan dari tubuh pasien yang sakit sebelum di bawa atau dibuang ke hutan maupun laut.

Bentuk dari Balai tersebut tercipta dari wahyu atau bayangan maupun mimpi Bomo terkait keinginan roh tersebut terhadap Balai yang diinginkannya. Balai dimiliki oleh masingmasing Bomo dan berebda antara Bomo satu dan lainya. Penaaman Balai juga tergantung dari wahyu yang disampaikan tersebut. Bentuk model rumah roh (huma hantu) juga berbeda antara pasien yang satu dengan yang lainya, bentuk ini juga disampaikan oleh roh ketika malam kedua pelaksanaan Bedekeh. Bentuk model rumah roh juga berebda tergantung jenis penyakit dan roh yang mendiami tubuh pasien. Kemana model rumah roh dibuang juga tergantung dari wahyu yang diterima oleh Bomo pada saat ritual Bedekeh dilangsungkan.

Proses pembuatan Balai dilakukan oleh Bomo dan keluarga Bomo. Pengerjaan Balai biasanya lebih lama, karena ukuran dan bentuk yang lebih rumit. Sedangkan pembuatan Model Rumah Roh dikerjakan oleh keluarga pasien, 
atau tentangga pasien. Proses pengerjaan model rumah roh lebih singkat, hanya satu hari saja. Penggunaan Model Balai bisa digunakan selama Bomo masih hidup, sedangkan pengunnan model rumah roh hanya sekali pakai atau disebut "Bebuang". Jika dilihat dari proses terciptanya bentuk dari Balai dan Rumah Roh tersebut, bentukan itu terlihat lazim, seperti bentuk dari rumah suku Akit itu sendiri. Bentuk-bentuk lain yang dikenal dilingkungan masyarakat setempat.

Dalam kajian etnografi, kita lebih memfokuskan pada proses dan makna yang terkandung didalamnya. Dalam penelitian ini, proses pengobatan yang dilakukan oleh Suku Akit bukan dimaknai sebagai bentuk kepercayaan, melainkan sebuah budaya yang diwariskan turun temurun. Maka komponen yang memegang peranan penting dalam etnografi komunikasi proses pengobatan suku Akit adalah Bomo yang berperan sebagai saluran komunikasi antara wahyu (roh baik) dengan si sakit. Selanjutnya komponen utama lainnya adalah si sakit sebagai objek dari proses pengobatan ini, namun yang menarik bukanlah individu si sakit melainkan peralatan atau barang kepunyaan si sakit yang merepresentasikan dirinya di hadapan wahyu pada saat proses pengobatan. Komponen terakhir dalam etnografi komunikasi pengobatan ini adalah wahyu itu sendiri. Wahyu bukan dimaknai sebagai tuhan, wahyu dianggap sebagai roh baik yang bertugas menjaga, melindungi, menyembuhkan dan perantara antara manusia dengan tuhannya. Wahyu hanya bisa berkomunikasi dengan Bomo, yang dipilih oleh wahyu. Hal ini menjadikan Bomo sebagai symbol dari proses komunikasi tersebut.

\section{DAFTAR PUSTAKA}

Anshori, D.S. (2017). Etnografi komunikasi; perspektif bahasa. Jakarta: Raja Grafindo Persada.

Eliade, M. (2004). Shamanism: Archaic techniques of ecstasy (2nd ed.). Prinston: Prinston University Press.

Fadhilah, S., \& Dewi, E. A. S. (2017). Pola komunikasi tradisi marosok antara sesama penjual dalam budaya dagang Minangkabau. Jurnal Kajian Komunikasi, 5(2), 222-234. Diakses dari http://jurnal. unpad.ac.id/jkk/article/view/10464.
Faisal, G., \& Wihardiyanto, D. (2016). A characteristic study on the designs and materials of the Talang Mamak tribe housing. In D. F. Swasto \& I. Hidayati (Eds.), 3rd Biennale ICIAP 2016 (pp. 289-295). Yogyakarta: Universitas Gadjah Mada.

Firzal, Y., Rijal, M., \& Faisal, G. (2017). Study of vernacular coastal architecture: The construction of Akit's house in Rupat island. Applied Science and Technology: Science and Technology for Improving Quality of Life, 1(1), 449-451.

Harsono, B., \& Jonyanis. (2014). Sistem perawatan kesehatan (berdukun berbara) pada suku Talang Mamak. Jurnal Online Mahasiswa (JOM) FISIP Universitas Riau, 1(2), 1-16. Diakses dari https://jom.unri. ac.id/index.php/JOMFSIP.

Khomsa, F. Al, \& Nurjanah. (2015). Strategi komunikasi pemasaran kafe Kopmil Ping 2 U Pekanbaru dalam mempertahankan loyalitas konsumen. Jurnal Online Mahasiswa (JOM) FISIP Universitas Riau, 2(2), 1-15. Diakses dari https://jom. unri.ac.id/index.php/JOMFSIP/article/ view/6978.

Kurniati, F. (2015). Representasi sebagai bentuk komunikasi dalam arsitektur. In Temu Ilmiah IPLBI 2015 (pp. 187-190). Lhokseumawe: IPLBI.

Leuape, E. S., \& Dida, S. (2017). Dialetika etnografi komunikasi emik-etik pada kain tenun. Jurnal Kajian Komunikasi, 5(2), 147-158. Diakses dari http://jurnal.unpad. ac.id/jkk/article/view/8637.

Limbeng, J. (2011). Suku Akit di pulau Rupat. Jakarta: Kementerian Pariwisata dan EkonomiKreatif. Diakses darihttps://books. google.co.id/books?id=tQbFCgAAQBAJ.

Malangyudo, A. S., \& Subroto, T. Y. W. (2013). Eksistensi konsep natah pada tata ruang rumah tinggal orang Bali di Yogyakarta. Jurnal Arsitektur Dan Perancangan, 6(2), 11-19.

Marlinda, E. S., Barliana, M. S., \& Krisnanto, E. (2013). Hubungan pengalaman berarsitektur dengan kreativitas desain mahasiswa. Journal INVOTEC-Inovation of Vocational Technology Education, IX(1), 1-16. Diakses dari http://ejournal.upi.edu/ index.php/invotec/article/view/4880. 
Octavianti, M. (2016). Komunikasi nonverbal proksemik di rumah tidak layak huni. Jurnal Kajian Komunikasi, 4(1), 10-27. https://doi.org/10.24198/jkk.v4i1.7547.

Osawa, T. (2009). Shamanistic practices among the akit of eastern Sumatra. Tokyo University. Diakses dari http://id.nii. ac.jp/1342/00000788/.

Samovar, L. A., Porter, R. E., \& McDaniel, E. R. (2010). Komunikasi lintas budaya (7th ed.). Jakarta: Salemba Humanika.

Suroyo, Wirata, G., \& Kamaruddin. (2017). Strategi pengelolaan pariwisata budaya ritual bedekeh suku Akit di pulau Rupat kabupaten Bengkalis provinsi Riau. In Proceeding 2nd TEAM 2017 (pp. 3339). Denpasar: Universitas Pendidikan Ganesha. Diakses dari http://eproceeding. undiksha.ac.id/index.php/team/index.

Syahrozi. (2013). Morfologi bentuk tampak (studi kasus huma gantung buntoi). Jurnal Perspektif Arsitektur, 8(1), 1-12. Diakses dari http://jurnalperspektifarsitektur.com/ vol-08-no-01-2013/morfologi-bentuktampak-studi-kasus-huma-gantung-buntoi.

Tandyonomanu, D., \& Bahfiarti, T. (2013). Seni ruang dan waktu dalam Mappacci pada upacara perkawinan adat Bugis. Jurnal Kajian Komunikasi, 1(1), 83-94. Diakses dari http://jurnal.unpad.ac.id/jkk/article/ view/6033.

Wardani, L. K. (2010). Fungsi, makna dan simbol (sebuah kajian teoritik). In Proseding Seminar Nasional Jelajah Arsitektur Nusantara ITS (pp. 291-300). Surabaya: Institut Teknologi Sepuluh Nopember. 